\title{
Effect of Aerosolization on the Transport of $\alpha$-Methyl Glucoside and Galactosides into Escherichia coli
}

\author{
By J. E. BENBOUGH, P. HAMBLETON, K. L. MARTIN \\ AND R. E. STRANGE \\ Microbiological Research Establishment, Porton, Salisbury, Wiltshire
}

(Received Io January 1972; revised 9 May 1972)

\begin{abstract}
SUMMARY
Aerosolization decreased the accumulation of methyl-[ $\alpha$-D-gluco]pyranoside $(\alpha \mathrm{MG})$ in two strains of Escherichia coli. The inactivation was apparently not due to damaged permeases but to detachment from the bacteria of components involved in the transport of substrates through bacterial membranes. Transport activity was partially restored when aerosolized bacteria were incubated with leaked components. Aerosolization also decreased accumulation of isopropyl-thio- $\beta$-Dgalactopyranoside (IPTG) by $E$. coli but increased permeability to $O$-nitrophenyl$\beta$-D-galactopyranoside (ONPG). Loss in viability of airborne bacterial populations correlated with the decrease in $\alpha \mathrm{MG}$ accumulation by bacteria recovered from aerosols one second after generation of the cloud.
\end{abstract}

\section{INTRODUCTION}

Aerosolization of Escherichia coli decreases their ability to synthesize certain macromolecules and concentrate ions (Anderson, 1966; Anderson \& Dark, 1967; Benbough, 1967; Anderson, Dark \& Peto, I968) and in dry atmospheres makes certain oxidative enzymes sensitive to oxygen (Benbough, $1967 ; 1969$ ). Aerosolization also causes changes in the structure and organization of the Gram-negative bacterial envelope. For example, alterations in the surface properties of $E$. coli (MRE strains 160 and I62) resulting from aerosolization change the electrophoretic mobility of the bacteria (J. E. Benbough, unpublished results) and aerosolized Gram-negative bacteria become sensitive to certain hydrolytic enzymes (Hambleton, I970).

Damage to the cytoplasmic membrane could seriously affect bacterial survival since a large number of metabolic functions are known to occur at, or are closely associated with, this structure. One such function is active transport which facilitates the movement of substances across the cytoplasmic membrane into micro-organisms, even against a concentration gradient. Active transport systems require energy and may involve certain proteins that act as substrate-specific carrier substances. The carriers bind to substrate molecules and facilitate movement of the substrate across the cytoplasmic membrane. Subsequent dissociation of the carrier-substrate complex at the inner membrane results in the release of the substrate (Fox \& Kennedy, 1965; Kepes, 197I). The discovery of the phosphoenolypyruvate-hexosephosphotransferase system (Kundig, Ghosh \& Roseman, 1964) and the use of $\left[{ }^{14} \mathrm{C}\right] \alpha \mathrm{MG}$ as a non-metabolizable analogue of glucose has increased understanding of the biochemistry of glucose transport across the cytoplasmic membrane of bacteria. Phosphorylation through the phosphotransferase system is an essential stage in the transportation of $\alpha \mathrm{MG}$ (and glucose) into bacteria (Roseman, 1969) and Gachelin (1970) showed that the rate of phosphorylation of $\alpha \mathrm{MG}$ is equal to the initial rate of entry of $\alpha \mathrm{MG}$ into Escherichia coli. Accumulated 
$\alpha \mathrm{MG}-\mathrm{P}$ is enzymatically dephosphorylated to give $\alpha \mathrm{MG}$ in the cytoplasm thus lowering the ratio $\alpha \mathrm{MG}-\mathrm{P}: \alpha \mathrm{MG}-\mathrm{P}+\alpha \mathrm{MG}$ from $\mathrm{I} \cdot \mathrm{O}$, at zero time, to a lower constant value when an equilibrium state is reached.

This paper reports damage to the transport system for $\alpha \mathrm{MG}$ in Escherichia coli and release of intracellular material when the bacteria are aerosolized and recovered into aqueous media.

\section{METHODS}

Growth of bacteria. Escherichia coli MRE strains 160 and 162 were grown in batch culture vessels $(500 \mathrm{ml})$ in a Porton type fermenter (Herbert, Phipps \& Tempest, 1965) with forced aeration. The temperature $\left(37 \pm 0 \cdot 2{ }^{\circ} \mathrm{C}\right)$ and $\mathrm{pH}(7 \cdot 35 \pm 0 \cdot 05)$ were maintained automatically. Two media were used, one in which bacterial growth ceased due to exhaustion of the carbon source and in the other exhaustion of the nitrogen source. The basic medium contained (g/l): $\mathrm{NaH}_{2} \mathrm{PO}_{4}, 0.775 ;\left(\mathrm{NH}_{4}\right)_{2} \mathrm{HPO}_{4}, 5.95 ; \mathrm{K}_{2} \mathrm{SO}_{4}, \mathrm{I} \cdot 75$; and salt mixture (I ml). The salt mixture was prepared by dissolving $\mathrm{MgO}, 50.4 \mathrm{~g} ; \mathrm{CaCO}_{3}, \mathrm{I} \cdot 0 \mathrm{~g} ; \mathrm{FeCl}_{3} .6 \mathrm{H}_{2} \mathrm{O}, 2.7 \mathrm{~g}$; $\mathrm{MnCl}_{2} .4 \mathrm{H}_{2} \mathrm{O}, \mathrm{I} \cdot 0 \mathrm{~g} ; \mathrm{ZnO}, 0.4 \mathrm{~g} ; \mathrm{CoCl}_{2} .6 \mathrm{H}_{2} \mathrm{O}, \mathrm{I} \cdot 2 \mathrm{~g} ; \mathrm{H}_{3} \mathrm{BO}_{3}, 0.3 \mathrm{~g} ; \mathrm{Na}_{2} \mathrm{MoO}_{4} .2 \mathrm{H}_{2} \mathrm{O}$, $\mathrm{I} \cdot 2 \mathrm{~g}$; and $\mathrm{CuCl}_{2} \cdot 2 \mathrm{H}_{2} \mathrm{O}, 0.34 \mathrm{~g}$, in the order given, in water $(500 \mathrm{ml})$ containing conc. $\mathrm{HCl}$ $(250 \mathrm{ml})$ and diluting to I 1 with water. The medium was sterilized by autoclaving ( $120^{\circ} \mathrm{C}$, I $5 \mathrm{~min})$. A sterile solution of glucose $(50 \%, 7 \mathrm{ml})$ was added to make the carbon-limited medium. For the nitrogen-limited medium $\left(\mathrm{NH}_{4}\right)_{2} \mathrm{HPO}_{4}$ was decreased to $0.495 \mathrm{~g}$, the ionic strength being maintained by adding $\mathrm{Na}_{2} \mathrm{HPO}_{4}(5 \cdot 85 \mathrm{~g})$ and glucose being added as a sterile solution $(50 \%, 20 \mathrm{ml})$.

Starvation of bacteria. Bacteria were starved for $24 \mathrm{~h}$ at $37^{\circ} \mathrm{C}$ with aeration (Strange, Dark \& Ness, I96I).

Preparations of spray suspensions, aerosol generation, storage and collection. Bacterial suspensions were harvested by centrifuging at room temperature (10000 g, $15 \mathrm{~min}$ ) washed twice with saline phosphate buffer ( $\mathrm{pH} \mathrm{6.5}$, Strange et al. 196I) and once with redistilled water, and resuspended in distilled water (final concentration of about $10^{10}$ organisms $/ \mathrm{ml}$ ). Bacterial aerosols were generated and stored as previously described (Benbough, 1969; Hambleton, 1970). Samples of aerosols were collected with Porton raised impingers (May \& Harper, I957) containing Io $\mathrm{ml}$ saline phosphate buffer $\left(\mathrm{g} / \mathrm{l}: \mathrm{NaCl}, 8 ; \mathrm{KCl}, 0.2 ; \mathrm{Na}_{2} \mathrm{HPO}_{4}\right.$, $\mathrm{I} \cdot \mathrm{I} 5 ; \mathrm{KH}_{2} \mathrm{PO}_{4}, 0.2 ; \mathrm{pH} 7.4$ ) which had previously been filtered through Millipore membranes (pore size $0.45 \mu \mathrm{m}$ ). More concentrated suspensions of aerosolized bacteria for radioactive uptake experiments were obtained by continuously sampling the cloud with 22 1/min impingers after it had travelled along the mixing tube for approximately I $\mathbf{s}$. Viabilities of suspensions were determined using a slide culture technique (Postgate, Crumpton \& Hunter, I96I). Concentrated suspensions of bacteria recovered from aerosols were centrifuged at room temperature (10000g, $15 \mathrm{~min}$ ) and the supernatant fluid removed. Aerosolized and control bacteria were washed twice in saline phosphate buffer $\left(\mathrm{pH}_{7} \cdot 4\right)$ and finally suspended at a concentration of $5 \times 10^{7}$ organisms $/ \mathrm{ml}$ in saline phosphate buffer $(\mathrm{pH} 7.4)$ containing 2 mM-magnesium chloride.

The uptake of methyl-[ $\alpha$-D-gluco $\left.{ }^{14} C\right]$ pyranoside $(\alpha M G)$. Washed suspensions of control and aerosolized bacteria $(4.5 \mathrm{ml})$ were incubated at $37^{\circ} \mathrm{C}$ for 10 min with gentle shaking; $\left[{ }^{14} \mathrm{C}\right] \alpha \mathrm{MG}(0.5 \mathrm{ml}$ I $\mu \mathrm{Ci} / \mathrm{ml}, 3.8 \mu \mathrm{Ci} / \mathrm{mmol}$ obtained from the Radiochemical Centre, Amersham, Buckinghamshire) was added. Samples ( $1 \cdot 0 \mathrm{ml}$ ) were removed from the incubation fluid at intervals and filtered through Millipore membrane filters (HAWP; $0.45 \mu \mathrm{m}$ pore size) soaked with water. The bacteria retained on the filters were washed three times with

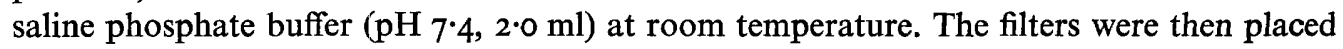


in glass vials and dried at $80^{\circ} \mathrm{C}$ for $5 \mathrm{~min}$. Scintillation fluid ( $\mathrm{IO} \mathrm{ml}$ ) containing 2,5-diphenyloxazole $(5 \mathrm{~g})+\mathrm{I}, 4$-bis-2-(4-methyl-5-phenyloxazolyl) benzene $(0.5 \mathrm{~g})$ (B.D.H. Chemicals Ltd, Poole, Dorset) per litre of toluene were added to each vial. The samples were counted in a Philips automatic liquid scintillation counter (N.V. Philips, Eindhoven, The Netherlands).

Extraction and chromatography of $\left[{ }^{14} C\right] \alpha M G$ and phosphorylated $\left[{ }^{14} C\right] \alpha M G$. After incubation with $\left[{ }^{14} \mathrm{C}\right] \alpha \mathrm{MG}$ samples $(\mathrm{I} \cdot 0 \mathrm{ml})$ of the bacterial suspension were centrifuged in a Quickfit Micro-Centrifuge type 320 (James A. Jobling \& Co. Ltd, Stone, Staffordshire) at $24000 \mathrm{~g}$ for I min at room temperature and the pellet treated with $5 \%(\mathrm{w} / \mathrm{v})$ trichloroacetic acid $(\mathrm{I} .0 \mathrm{ml})$ at $0^{\circ} \mathrm{C}$ for $\mathrm{I} \mathrm{h}$. The suspensions were again centrifuged at $24000 \mathrm{~g}$ for $\mathrm{I} \mathrm{min}$, the supernatant fluid removed and its $\mathrm{pH}$ adjusted to 8.5 with $\mathrm{N}-\mathrm{NaOH}$. A portion of this extract $(20 \mu 1)$ was analysed by ascending chromatography on $2 \mathrm{~cm}$ wide paper strips (Whatman no. I chromatography paper). Chromatograms were developed for $90 \mathrm{~min}$ at room temperature with the solvent $\mathrm{CH}_{3} \mathrm{OH}+\mathrm{NH}_{4} \mathrm{OH}(30 \%)+\mathrm{H}_{2} \mathrm{O}(6: \mathrm{I}: 3$ by vol.). Chromatograms were subsequently dried and cut into $0.5 \mathrm{~cm}$ strips which were placed in vials.

Scintillation fluid $(5.0 \mathrm{ml})$ was added to the vials and radioactivity measured as before. Two labelled components were detected and one $\left(R_{F}, 0 \cdot 78\right)$ was identified as $\alpha \mathrm{MG}$ using $\left[{ }^{14} \mathrm{C}\right] \alpha \mathrm{MG}$ as a marker. The other component $\left(R_{F}, 0.63\right)$ was identified as phosphorylated $\alpha \mathrm{MG}$ by incubating a portion of the extract with alkaline phosphatase $(50 \mu \mathrm{g} / \mathrm{ml})$ (B.D.H. Chemical Ltd, Poole, Dorset) at $37^{\circ} \mathrm{C}$ for $\mathrm{I} \cdot 5 \mathrm{~h}$. This converted the radioactive material into a single labelled component $\left(R_{F}, 0 \cdot 78\right)$ and phosphate.

Dialysis of bacterial exudate. Exudate released from aerosolized bacteria into the collection fluid was separated by centrifuging ( $10000 \mathrm{~g}$, I $5 \mathrm{~min}$; room temperature) the bacterial suspension and filtering the supernatant fluid through a Millipore membrane (HAWP: $0.45 \mu \mathrm{m}$ ). The exudate was fractionated into high- and low-molecular-weight fractions by pressure dialysis at $0{ }^{\circ} \mathrm{C}$ using a 'Diaflo' ultrafiltration cell (Amicon Corp., Lexington, Massachusetts, U.S.A.) fitted with a membrane permeable to molecules of less than 5000 mol. wt. Pressure in the ultrafiltration cell was maintained with nitrogen $\left(30 \mathrm{lb} / \mathrm{in}^{2}\right)$ and the fluid was continuously stirred.

Bacterial dry weights. The method described by Strange et al. (196I) was used.

Protein determination. The method of Lowry, Rosebrough, Farr \& Randall (I95I) was used in a Technicon AutoAnalyser (Wade \& Phillips, 1971).

Nucleic acid and nucleotide estimation. The concentration of nucleic acid and nucleotides in the exudate from aerosolized bacteria were calculated from the extinction values of samples at $260 \mathrm{~nm}$ measured with a Unicam SP 500 spectrophotometer.

Gel electrophoresis. The cell exudate was concentrated approximately 200 -fold by pressure dialysis and proteins in the concentrate were separated by electrophoresis on cellogel strips (Chemetron, Milan, Italy) for $4 \mathrm{~h}$ at $5.0 \mu \mathrm{A} / \mathrm{cm}$ and $18 \mathrm{~V} / \mathrm{cm}$. Protein bands were stained with Ponceau $\mathrm{S}$ followed by destaining of the gel strips (Cellogel instruction sheet, Chemetron, Milan).

Enzyme assays. Acid hexosephosphatase and cyclic phosphodiesterase were estimated with the methods of Neu \& Heppel (1965), glucose-6-phosphate dehydrogenase activity with the method of Malamy \& Horecker (I96I) and lactic dehydrogenase with the method of Stolzenbach (1966).

Uptake of $\left[{ }^{14} \mathrm{C}\right] 2$-isopropyl-thio- $\beta$-D-galactopyranoside $(I P T G)$. The method was similar to that used for measuring the uptake of $\left[{ }^{14} \mathrm{C}\right] \alpha \mathrm{MG}$ using $\left[{ }^{14} \mathrm{C}\right] \mathrm{IPTG}(\mathrm{I} \mu \mathrm{Ci} / \mathrm{ml})$ of specific activity $25 \mu \mathrm{Ci} / \mu \mathrm{mol}$ (Calbiochem Ltd, London). In some experiments $\beta$-galactosidase synthesis was induced by the addition of IPTG (0.I mM, Anderson, I966; Rickenberg, 


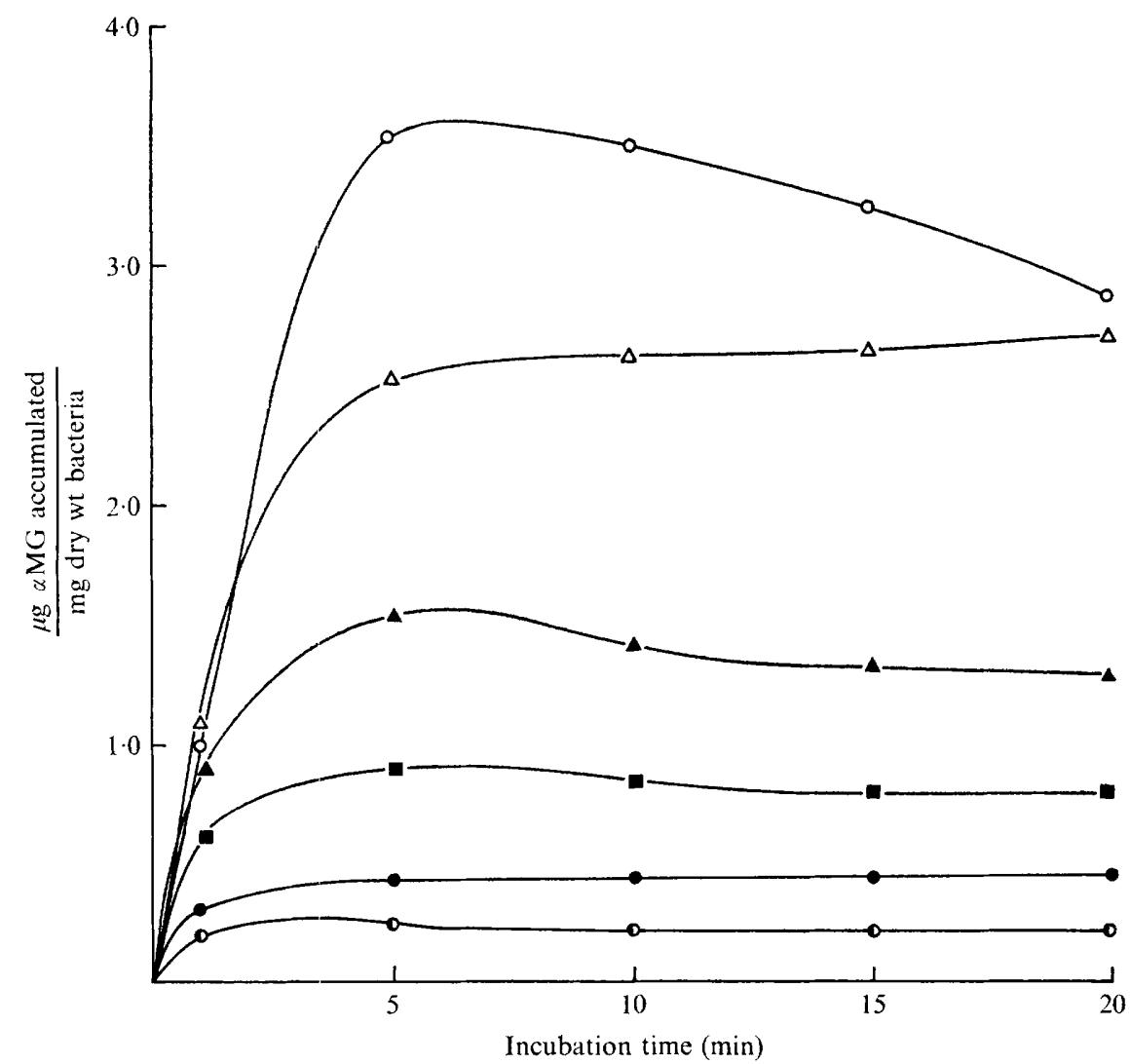

Fig. I. The effect of aerosolization on the accumulation of $\left[{ }^{14} \mathrm{C}\right] \alpha \mathrm{MG}$ by Escherichia coli MRE I 60 and and MRE162. Washed suspensions of exponential phase control and aerosolized bacteria $\left(5 \times 10^{7}\right.$ organisms $/ \mathrm{ml})$ were incubated for $20 \mathrm{~min}$ at $37{ }^{\circ} \mathrm{C}$ with $\left[{ }^{14} \mathrm{C}\right] \alpha \mathrm{MG}(0 \cdot \mathrm{I} \mu \mathrm{Ci} / \mathrm{ml}, 3 \cdot 8 \mu \mathrm{Ci} / \mathrm{mmol})$ and the uptake of radioactivity determined at intervals. Escherichia coli 160 control, $\bigcirc$; aerosolized at $70 \%$ relative humidity (r.h.), $\odot$; and $40 \%$ r.h., $\odot$, for I s; E. coli 162 , control, $\triangle$; aerosolized at $70 \%$ r.h., $\boldsymbol{\Delta}$; and $40 \%$ r.h., $\mathbf{\square}$, for I s.

Cohen, Buttin \& Monod, 1956) to the glucose-salts growth medium. Bacteria were harvested during the exponential growth phase and washed as described above.

Uptake of $O$-nitrophenyl- $\beta$-D-galactopyranoside (ONPG). To portions of washed suspensions of control and aerosolized bacteria $(27 \mathrm{ml})$ were added $3.0 \mathrm{ml} 0.015 \mathrm{M}-\mathrm{ONPG}$. The mixtures were incubated at $37^{\circ} \mathrm{C}$ and samples $(5.0 \mathrm{ml})$ were removed at $5 \mathrm{~min}$ intervals. M-Sodium carbonate $(3 \mathrm{ml})$ was added to each sample, the mixtures filtered through Whatman no. I paper and $O$-nitrophenol determined spectrophotometrically at $420 \mathrm{~nm}$.

Materials. 'Analar' grade chemicals were used wherever possible and, with glucose-6phosphate, were obtained from B.D.H. Chemicals Ltd, Poole, Dorset. Ribose, phosphoenol pyruvate (monocyclohexylammonium salt) and $O$-nitrophenyl- $\beta$-D-galactopyranoside were from Koch-Light Laboratories Ltd, Colnbrook, Buckinghamshire, and fructose from George T. Gurr Ltd, London, S.W. 6. ATP was from C. F. Boehringer \& Soehne Gmbh., Mannheim, W. Germany. 


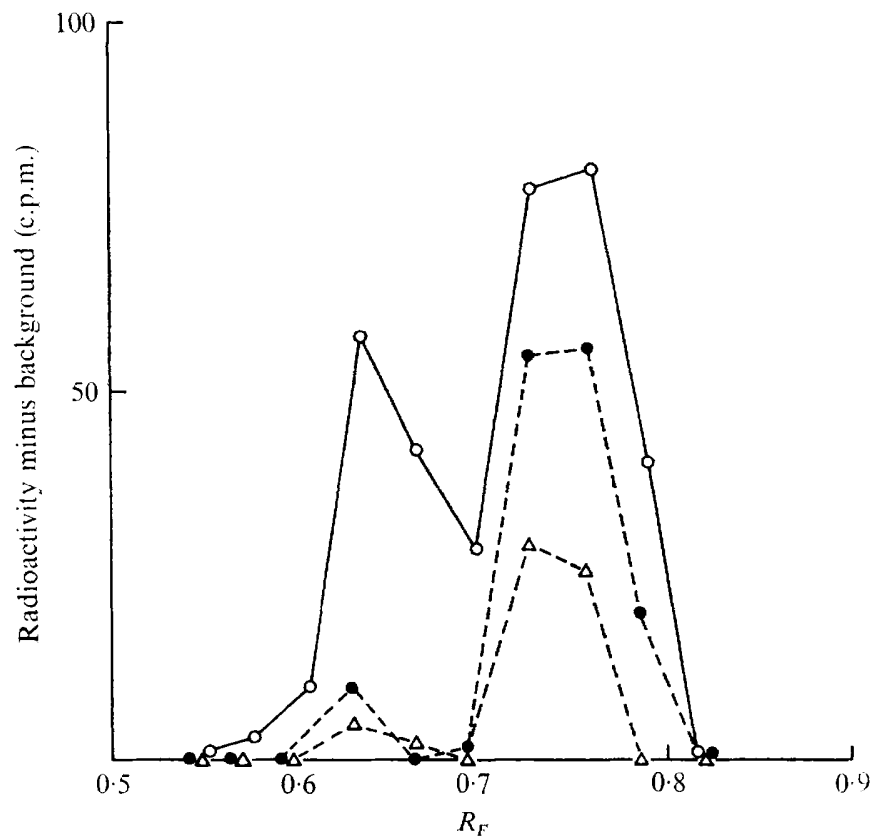

Fig. 2. The exit of $\alpha M G$ and phosphorylated- $\alpha M G$ from Escherichia coli MrE 160 . Washed suspensions of exponential phase bacteria $\left(5 \times 10^{7}\right.$ organisms $\left./ \mathrm{ml}\right)$ were incubated for 10 min at $37{ }^{\circ} \mathrm{C}$ with $\left[{ }^{14} \mathrm{C}\right] \propto \mathrm{MG}(\mathrm{I} \mu \mathrm{Ci} / \mathrm{ml}, 3.8 \mu \mathrm{Ci} / \mathrm{mmol}) .\left[{ }^{14} \mathrm{C}\right] \alpha \mathrm{MG}\left(R_{F}, 0.78\right)$ and phosphorylated $\left[{ }^{14} \mathrm{C}\right] \propto \mathrm{MG}\left(R_{F}\right.$, $0.63)$ in cold $5 \%(\mathrm{w} / \mathrm{v})$ trichloro-acetic acid extracts of the bacteria were analysed by paper chromatography immediately before $(O)$ and at the following times ( $.5 \mathrm{~min}, 0$, and $2.5 \mathrm{~min}, \triangle$ ) after the addition of unlabelled $\alpha \mathrm{MG}(260 \mu \mathrm{M})$ to the bacterial suspensions.

\section{RESULTS}

Escherichia coli strains MRE I60 and $\mathrm{I} 62$ accumulated $\left[{ }^{14} \mathrm{C}\right] \alpha \mathrm{MG}$ (Fig. I). The rapid initial rate of uptake decreased to a steady state when the rate of radioactivity influx balanced the efflux rate (Winkler, 197I). The steady-state intracellular concentrations of $\alpha \mathrm{MG}$ in $E$. coli MREI60 and MREI62 were respectively about 300 and 200 times those in the suspending media. Aerosolization and recollection after $\mathrm{I} s$ in the airborne state markedly affected the steady-state concentration of $\alpha \mathrm{MG}$ in the bacteria (Fig. I). Diminished uptake of $\alpha \mathrm{MG}$ following aerosolization was more pronounced with $E$. coli MREI60 than with MREI62; this is probably a reflexion of the poorer aerosol survival of the former compared to the latter. All other experiments reported were done with both strains with similar though quantitatively different results. The concentrations of phosphorylated $\alpha \mathrm{MG}(\alpha \mathrm{MGP})$ to free $\alpha \mathrm{MG}$ in the steady state were in the ratio of I to I.7 (Fig. 2). Adding unlabelled $\alpha \mathrm{MG}$ (260 $\mu \mathrm{M}$ ) displaced radioactivity from the bacteria into the surrounding medium, $\alpha$ MGP being very rapidly displaced while free $\alpha \mathrm{MG}$ was displaced more slowly. No $\alpha \mathrm{MGP}$ was detected in the surrounding medium, indicating that this compound undergoes dephosphorylation before or during the exit process from bacteria.

A decrease in the steady-state concentration of $\alpha \mathrm{MG}$ in aerosolized bacteria does not necessarily indicate a decreased rate of entry since a similar effect would be observed if aerosolization affected the retention of $\alpha \mathrm{MG}$ by bacteria. The losses of radioactivity that occurred after unlabelled $\alpha \mathrm{MG}(260 \mu \mathrm{M})$ was added to aerosolized and unaerosolized Escherichia coli were measured (Fig. 3). For these experiments the concentration of $\left[{ }^{14} \mathrm{C}\right] \alpha \mathrm{MG}$ 


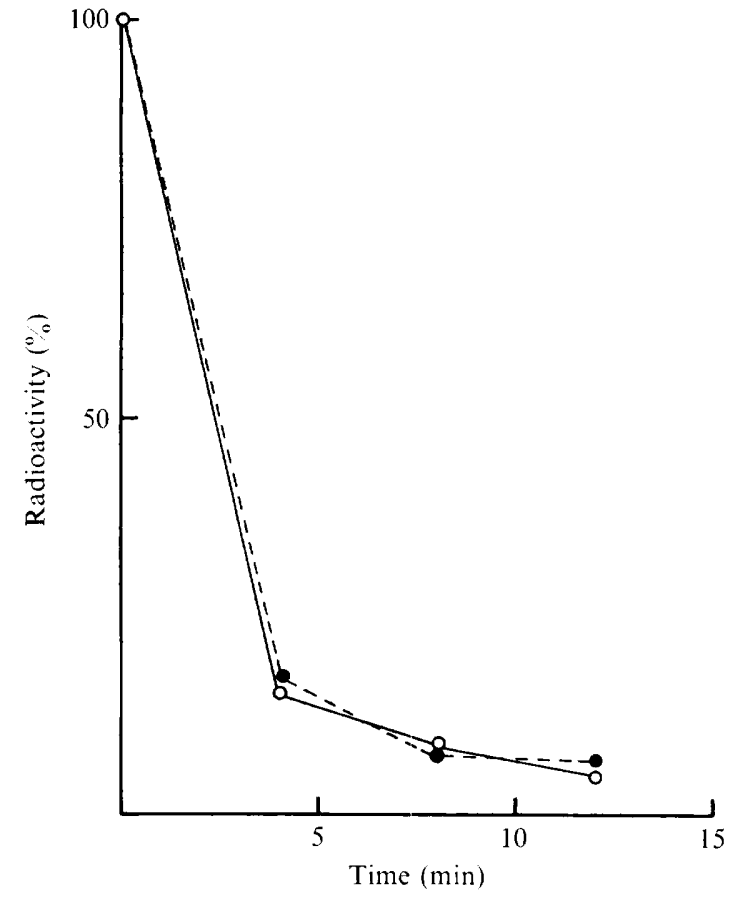

Fig. 3

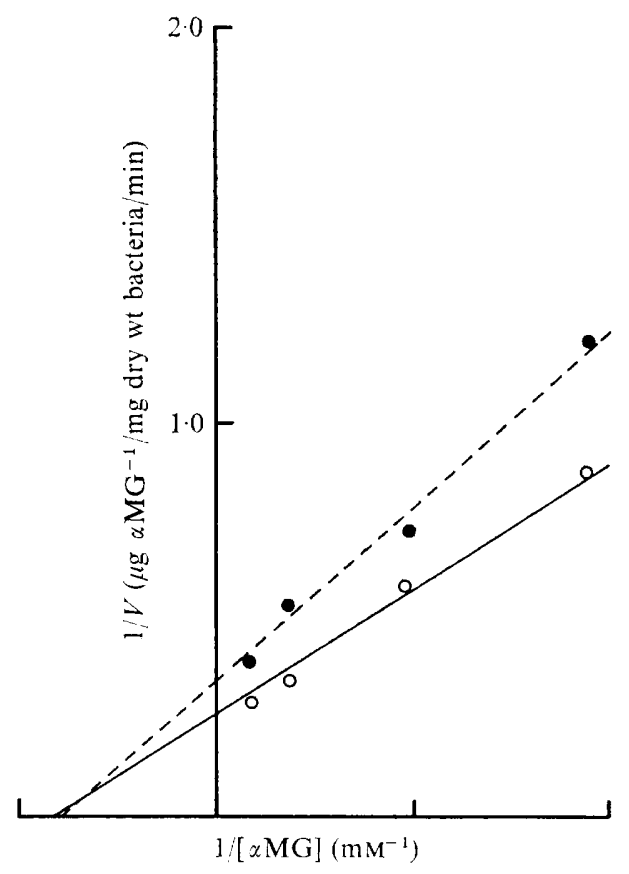

Fig. 4

Fig. 3. The rate of exit of accumulated radioactivity from control and aerosolized Escherichia coli MREI62. Control bacteria (O) were labelled by incubation with $\left[{ }^{14} \mathrm{C}\right] \alpha \mathrm{MG}(25.6 \mu \mathrm{M}, 3.8 \mu \mathrm{Ci} / \mathrm{mmol})$ and aerosolized (40\% r.h., I s) bacteria ( ) by incubation with $\left[{ }^{14} \mathrm{C}\right] \propto \mathrm{MG}(78 \mu \mathrm{M}, 3.8 \mu \mathrm{Ci} / \mathrm{mmol})$ for Io min. Unlabelled $\alpha$ MG $(260 \mu \mathrm{M})$ was then added and the exit of radioactivity followed.

Fig. 4. Lineweaver-Burk plot of the initial rates of uptake of $\left[{ }^{14} \mathrm{C}\right] \alpha \mathrm{MG}$ by control $(\mathrm{O})$ and aerosolized (40\% r.h., I s) (O) Escherichia coli MREI 6o, at various concentrations of $\alpha \mathrm{MG}$.

in the surrounding medium was increased to $78 \mu \mathrm{M}$ with aerosolized bacteria compared to $25.6 \mu \mathrm{M}$ with control bacteria to ensure similar radioactive uptake. The ratio of $\alpha \mathrm{MG}$ to $\alpha$ MGP in aerosolized bacteria was the same as in control bacteria.

From values for the initial rate of uptake of $\alpha \mathrm{MG}$ by bacteria in the presence of increasing concentrations of the substrate, the calculated $K_{m}$ value for both aerosolized and control bacteria was $6 \cdot \mathrm{I} \times \mathrm{IO}^{-5} \pm 0.2$ (Fig. 4). This suggests that the diminished transport of $\alpha \mathrm{MG}$ into stressed bacteria was not due to decreased affinity of components of the active transport system towards $\alpha \mathrm{MG}$. One interpretation is that, during the spraying process and storage or collection of aerosols, materials involved in active transport are released from bacteria. Considerable quantities of cellular material were detected in the collecting fluid of bacteria recovered from aerosols; these included nucleic acids and some large molecular weight oligonucleotides ( $150 \mu \mathrm{g} / \mathrm{mg}$ dry wt bacteria), nucleotides ( $28 \mu \mathrm{g} / \mathrm{mg}$ dry wt bacteria) and proteins ( $26 \mu \mathrm{g} / \mathrm{mg}$ dry wt bacteria). Gel electrophoresis of the concentrated exudate showed that several distinct protein components were present but these have not been characterized.

Significant amounts of periplasmic enzymes were released from aerosolized bacteria into the collecting fluid but the total amounts recovered after aerosolization were much less than the levels in control bacteria. As enzyme activities were measured in vitro under optimal conditions the losses of activity were presumably due to damage to the enzymes caused by aerosolization. For example, the total amounts of acid-hexose phosphatase and cyclic 


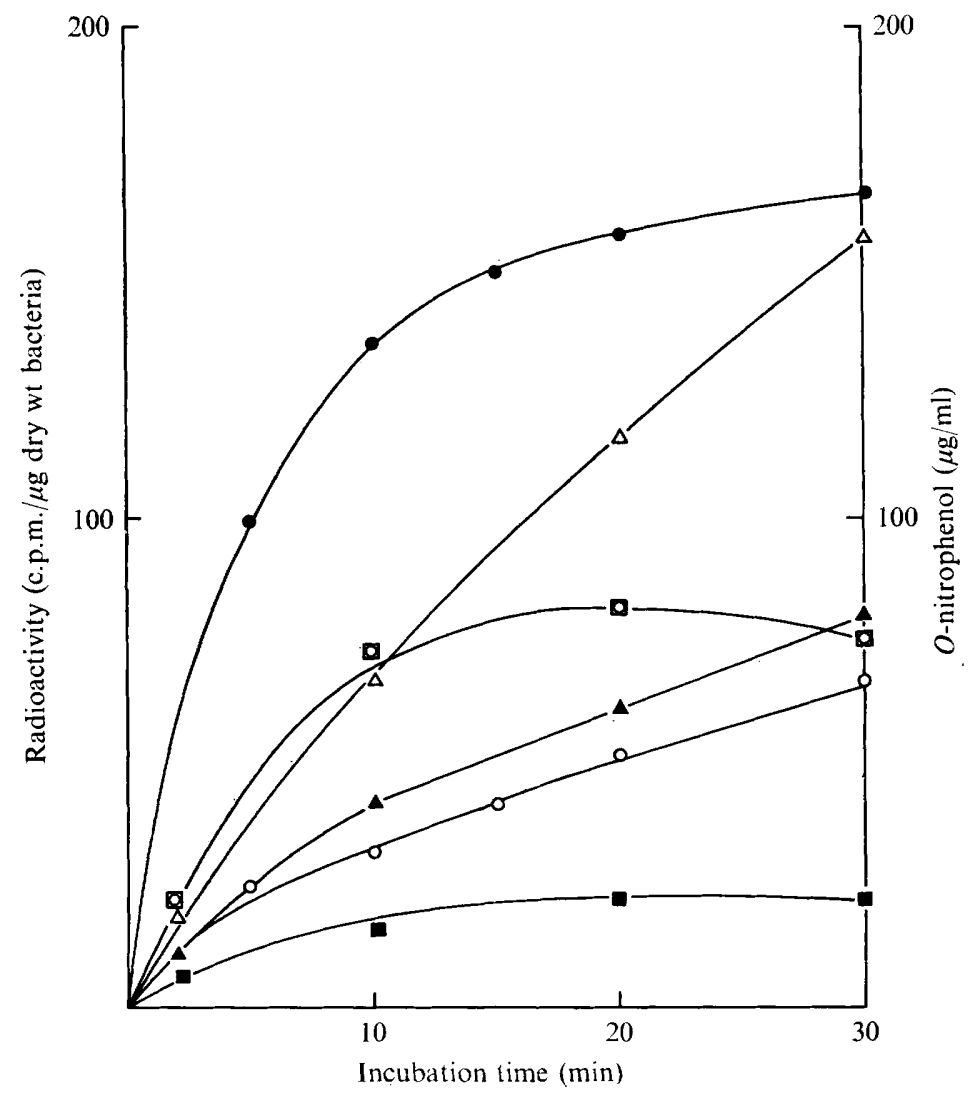

Fig. 5. The effect of aerosolization on accumulation of IPTG and ONPG by washed suspensions of Escherichia coli MRE 60 . The accumulation by control and aerosolized bacteria ( $40 \%$ r.h., I s) was measured as described in Methods. IPTG uptake: control bacteria-non-induced, $\boldsymbol{\square}$; induced, $\triangle$; aerosolized bacteria - non-induced, $\boldsymbol{\square}$; induced, $\boldsymbol{\Delta}$. ONPG uptake: control bacteria, 0 ; aerosolized bacteria, 0 .

phosphodiesterase activities recovered were only 13.4 and $20.7 \%$, respectively, of those found in control bacteria. About $85 \%$ of the activity of a cytoplasmic enzyme, lactic dehydrogenase, was also lost during aerosolization and collection but glucose-6-phosphate dehydrogenase was apparently unaffected.

When washed bacteria recovered from aerosols were incubated with concentrated exudate the uptake of $\alpha \mathrm{MG}$ was increased from I 6 to $30 \%$ of that by the control Escherichia coli 160. The stimulating effect of exudate was unchanged when its concentration in the incubation medium was doubled. The active constituents in the exudate were dialysable and heatstable ( $\mathrm{I}$ h at $60^{\circ} \mathrm{C}$, Io min at $90^{\circ} \mathrm{C}$ ). The accumulation of $\alpha \mathrm{MG}$ by non-aerosolized bacteria was unaffected by exudate. Partial inactivation of active transport caused by aerosolization may be due to the leakage of small molecular weight materials from the bacteria, but the addition of certain small molecular weight substances (cations, phosphoenolpyruvate, glucose-6-phosphate, adenosine triphosphate, hexoses and glycerol) did not stimulate uptake of $\alpha \mathrm{MG}$.

Accumulation of $\beta$-D-galactopyranosides. Anderson (1966) showed that synthesis of $\beta$-galactosidase by Escherichia coli $\mathrm{I} 60$ in response to the inducer IPTG was severely affected 
Table $\mathrm{x}$. Viabilities and $\alpha M G$ transport activities of Escherichia coli MREI 62 recovered from aerosols stored at various relative humidities

The bacteria were harvested from exponentially growing cultures $\alpha \mathrm{MG}$ transport was measured in bacteria stored for I $\mathbf{S}$ after aerosolization.

\begin{tabular}{|c|c|c|c|c|}
\hline \multirow{2}{*}{$\begin{array}{l}\text { Storage } \\
\text { relative humidity } \\
(\%)\end{array}$} & \multicolumn{3}{|c|}{$\begin{array}{l}\text { Viability after storage for } \\
\text { following times }(\%)\end{array}$} & \multirow{2}{*}{$\begin{array}{c}\alpha \text { MG transport } \\
\text { activity }(\%) \\
\text { control }=100 \%\end{array}$} \\
\hline & I S & $15 \mathrm{~min}$ & $30 \mathrm{~min}$ & \\
\hline $\begin{array}{l}40 \\
60\end{array}$ & $\begin{array}{l}83 \\
84\end{array}$ & $\begin{array}{l}12 \\
20\end{array}$ & $\begin{array}{r}3 \\
16\end{array}$ & $\begin{array}{l}3 \mathrm{I} \\
50\end{array}$ \\
\hline 75 & 78 & 18 & 15 & 50 \\
\hline 92 & 92 & 83 & 75 & 78 \\
\hline
\end{tabular}

Table 2. Relationship between growth conditions, inactivation of $\alpha M G$ transport and loss of viability of Escherichia coli MRE 162 aerosolized at $40 \%$ r.h.

Growth conditions

Exponential phase

Exponential phase

Stationary phase carbon-limited

Stationary phase carbon-limited

Stationary phase nitrogen-limited

Stationary phase nitrogen-limited

$\begin{array}{cc}\alpha \mathrm{MG} \text { transport } \\ \text { activity* } \\ \text { Starved } & (\%)\end{array}$

$-$

$+58$

$-57$

$+\quad 61$

$-\quad 73$

$+\quad 95$
Mean $\uparrow$ viability

(\%)

8

32

33

42

48

80

* Expressed as $\frac{\alpha \mathrm{MG} \text { concentration in steady state in bacteria recovered from I s aerosol }}{\alpha \mathrm{MG} \text { concentration in steady state in control (unsprayed) bacteria }} \times 100$.

$\dagger$ Expressed as the mean of the viability after $15 \mathrm{~min}$ and $30 \mathrm{~min}$ storage in the aerosol.

by aerosolization. Since aerosolization affects $\alpha \mathrm{MG}$ accumulation by bacteria it might also decrease the ability of aerosolized $E$. coli to concentrate IPTG intracellularly and hence cause the diminished synthesis of $\beta$-galactosidase. Uptake of $\left[{ }^{14} \mathrm{C}\right] \mathrm{IPTG}$ was decreased in aerosolized bacteria whether or not they had been induced, but ONPG entered E. coli MREI60 more readily after aerosolization (Fig. 5 ). The different effects of aerosolization on the ability of bacteria to transport IPTG and ONPG may be explained by differences in the transport mechanisms for the two substances. Transport of IPTG was inhibited by 60 mm-sodium azide whereas that of ONPG was unaffected, confirming that the transport of the former, but not of the latter, is an energy-dependent process as shown by Koch (I964).

Factors affecting $\alpha M G$ transport in aerosolized Escherichia coli. Bacteria recovered from aerosols approximately one second after spraying were substantially viable (between 70 and $100 \%$ ) although defective in transport mechanisms for $\alpha \mathrm{MG}$ and IPTG. When, however, bacteria were held in aerosol for longer periods, they died at a rate depending on their physiological state and environmental factors including r.h. (relative humidity). When these factors were varied, a positive correlation was found between immediate loss in activity of the transport system and survival of the bacteria held for longer periods in aerosol (Tables I, 2). Populations of exponentially growing bacteria sprayed immediately after harvesting were the least stable in aerosols and showed the greatest decrease in accumulation of $\alpha \mathrm{MG}$ after I $\mathrm{s}$ in the aerosol. The most resistant bacteria examined were those starved for $24 \mathrm{~h}$ after harvesting from nitrogen-limited medium; these bacteria survived well in aerosols and their ability to accumulate $\alpha \mathrm{MG}$ was little affected by aerosolization for $\mathrm{r}$ s. 


\section{DISCUSSION}

To discover the mechanism of the lethal action of aerosolization on bacteria, structural and/or biochemical changes must be identified before the death of a significant proportion of the population. Otherwise it is not clear whether the changes cause death or vice versa. In the present work we investigated certain changes that occurred when bacteria were held in an aerosol for only I s during which time the loss of viability was usually less than $20 \%$. Although aerosolization under these conditions affected certain periplasmic enzymes, suggesting that permeases may have been inactivated, it did not affect the affinity of the permease for $\alpha \mathrm{MG}$. Osmotic shock decreases transport of $\beta$-galactosides, amino acids and sulphate ions by releasing specific binding proteins from the bacteria (Pardee, I966; Anraku, 1967; Anraku \& Heppel, 1967) and therefore a similar release of some components of the phosphoenolpyruvate-hexose-phosphotransferase system into the surrounding medium during rehydration of aerosolized bacteria could similarly affect $\alpha \mathrm{MG}$ transport. Aerosolization causes of loss of control of permeability for $\mathrm{K}^{+}$ions (Anderson \& Dark, 1967) which are essential co-factors in the phosphoenolpyruvate-phosphotransferase reaction; this may be an additional factor contributing to diminished $\alpha \mathrm{MG}$ transport. $\alpha \mathrm{MG}$ transport activity was partially restored by exudate from aerosolized bacteria suggesting that binding proteins were present. Increased concentrations of exudate did not further increase uptake suggesting that repair of the transport system may require integration of binding compounds into the membrane.

Since most of the bacteria recovered I $\mathrm{s}$ after aerosol generation were still viable but had decreased biochemical activities, these decreases must either be reversible or not immediately lethal. There was a correlation between the extent of damage to active transport and subsequent longer time survival in the aerosol so that loss of transport activity may be one of the factors contributing to the lethal effect of aerosolization and recollection on bacteria. Division of osmotically shocked bacteria only takes place after replacement of enzymes and binding proteins lost from the stressed organisms (Heppel, 1969) while complete restoration of resistance to lysozyme precedes division of bacteria recovered from aerosols (Hambleton, 197I). Thus adequate repair and replacement of exuded transport components and other components (cytoplasmic and periplasmic enzymes, nucleic acids) would seem to be necessary before division and growth of rehydrated aerosolized Escherichia coli can take place.

The authors thank Mrs S. M. Marriott and MrS. Thompson for skilled technical assistance.

\section{REFERENCES}

Anderson, J. D. (1966). Biochemical studies of lethal processes in aerosols of Escherichia coli. Journal of General Microbiology 45, 303-3I 3 .

Anderson, J. D. \& DARK, F. A. (I967). Studies on the effects of aerosolization on the rates of efflux of ions from populations of Escherichia coli strain B. Journal of General Microbiology 46, 95-105.

Anderson, J. D., Dark, F. A. \& Peto, S. (I968). The effect of aerosolization upon survival and potassium retention by various bacteria. Journal of General Microbiology 52, 99-105.

ANRAKU, Y. (1967). The reduction and restoration of galactose transport in osmotically shocked cells of Escherichia coli. Journal of Biological Chemistry 242, 793-814.

Anraku, Y. \& HePpel, L. A. (1967). On the nature of the changes induced in Escherichia coli by osmotic shock. Journal of Biological Chemistry 242, 256I-2569.

Benbough, J. E. (1967). Death mechanisms in airborne Escherichia coli. Journal of General Microbiology 47, $325-333$.

Benbough, J. E. (1969). Factors affecting the toxicity of oxygen towards airborne coliform bacteria. Journal of General Microbiology 56, 241-250. 
Fox, C. F. \& KENNEDY, E. P. (1965). Special labelling and partial purification of the M protein. A component of the $\beta$-galactoside transport system of Escherichia coli. Proceedings of the National Academy of Sciences 54, $89 \mathrm{I}-899$.

Gachelin, G. (I970). Studies of the $\alpha$-methylglucoside permease of Escherichia coli. European Journal of Biochemistry 16, 342-357.

Hambleton, P. (1970). The sensitivity of Gram-negative bacteria, recovered from aerosols, to lysozyme and other hydrolytic enzymes. Journal of General Microbiology 6r, 197-204.

Hambleton, P. (I97I). Repair of wall damage in Escherichia coli recovered from an aerosol. Journal of General Microbiology 69, 81-88.

HePpel, L. A. (1969). The effect of osmotic shock on release of bacterial proteins and on active transport. Journal of General Physiology 54, 95-I09.

Herbert, D., Phipps, P. \& Tempest, D. W. (I965). The chemostat: design and instrumentation. Laboratory Practice 14, I1 50-I16I.

KEPES, A. (I97I). The $\beta$-galactoside permease of Escherichia coli. Journal of Membrane Biology 4, 87-I I 2.

Koch, A. L. (1964). The role of permease in transport. Biochemica et biophysica acta 79, 177-200.

Kundig, W., Ghosh, S. \& Roseman, S. (1964). Phosphate bound to histidine in a protein as an intermediate in a novel phosphotransferase system. Proceedings of the National Academy of Sciences of the United States of America 52, 1067-1074.

Lowry, O. H., Rosebrough, N. J., Farr, L. A. \& Randall, R. J. (195I). Protein measurement with the Folin phenol reagent. Journal of Biological Chemistry r93, 265-275.

MALAMY, M. \& HoreCKER, B. L. (I96I). The localization of alkaline phosphatase in E. coli KI2. Biochemical \& Biophysical Research Communications 5, 104-108.

MAY, K. R. \& HARPER, G. J. (I957). The efficiency of various liquid impinger samplers in bacterial aerosols. British Journal of Industrial Medicine I4, 287-297.

Neu, H. C. \& Heppel, L. A. (I965). Release of enzymes from Eschericheria coli by osmotic shock and during the formation of spheroplasts. Journal of Biological Chemistry 240, 3685-3692.

PARdeE, A. B. (1966). Purification and properties of a sulfate-binding protein from Salmonella typhimurium. Journal of Biological Chemistry 241, 5886-5892.

Postgate, J. R., Crumpton, J. E. \& Hunter, J. R. (I96I). The measurement of bacterial viability by slide culture. Journal of General Microbiology 24, I 5-24.

Rickenberg, H. V., Cohen, G. N., Buttin, G. \& Monod, J. (1956). La galactoside-perméase d'Escherichia coli. Annals Institute Pasteur 91, 829-857.

Roseman, S. (I969). The transport of carbohydrates by a bacterial phosphotransferase system. Journal of General Physiology 54, 138s-180s.

Stolzenbach, F. (1966). In Methods in Enzymology, vol. Ix, pp. 278-288. Edited by W. A. Wood. New York and London: Academic Press.

Strange, R. E., Dark, F. A. \& Ness, A. G. (196I). The survival of stationary phase Aerobacter aerogenes stored in aqueous suspension. Journal of General Microbiology 25, 6I-76.

WADE, H. E. \& PhILliPs, B. P. (I97I). Automated determination of bacterial asparaginase and glutaminase. Analytical Biochemistry 44, I89-199.

WINKLER, H. H. (I97I). Efflux and the steady state in $\alpha$-methyl-glucoside transport in Escherichia coli. Journal of Bacteriology 106, 362-368. 